\title{
The Quality of Pharmaceutical Services in the New Normal Era on Outpatient Loyalty at the Pharmacy Installation of the Daya General Hospital
}

\author{
Gemy Nastity Handayany* (D) \\ Department of Pharmacy, Alauddin State Islamic University, Makassar, Indonesia
}

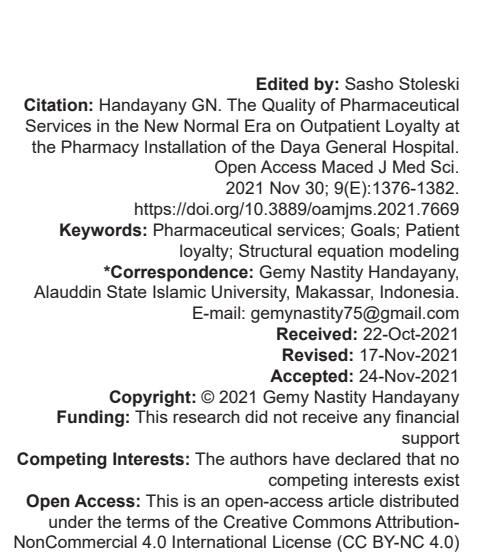

\section{Introduction}

Since the World Health Organization declared Coronavirus Disease 2019 (COVID-19) as a global pandemic on March 11, 2020, many countries have begun to implement strategies and alertness to the pandemic control of the transmission of COVID-19, including Indonesia. In Indonesia, the implementation of the emergency response period for handling COVID-19 began in March 2020. It was followed by the modification of the zoning policy to Large-Scale Social Restrictions (in Indonesian: Pembatasan Sosial Berskala Besar, abbreviated as PSBB) in April 2020, the first to be implemented in the Jakarta area. Three months later, the COVID-19 pandemic led to a new order of life called the new normal, which began on June 1, 2020, and less the physical distancing, known as PSBB in Indonesian.

New normal is a new order that led people to adapt to COVID-19 through the freedom to carry out activities requiring the implementation of health protocols. Gradually, the new normal started and brought many changes to people's lifestyles and public services. Given the importance of health in the new normal, health-care providers must compete to provide the best service to increase competitiveness; an example of a large-scale health-care provider is a hospital.

The Daya General Hospital of Makassar City has increased public health by developing a financing system for each health service at an affordable rate. The Hospital Pharmacy Installation is the only unit that provides pharmaceutical preparations, manages, and distributes them to hospital patients and is fully responsible for distributing and presenting information on pharmaceutical preparations for all parties in the hospital. According to Rusly (2016), the Pharmacy Installation is one of the main installations because more than $90 \%$ of health services in hospitals use pharmaceutical supplies, including drugs, chemicals, radiology materials, consumable medical devices, and medical devices medical gases, and $50 \%$ of the total hospital income comes from pharmaceutical supplies [1].

The role of pharmacists in pharmacy installations has expanded from drug-oriented services to patient-centered services. It may improve therapy outcomes and minimize risks with the aim of patient safety to ensure the quality of patient life [2]. Pharmaceutical services are fully involved in hospitals' service quality control program, and these services 
must be evaluated gradually to achieve sustainable service quality.

The results of this study were expected to provide an overview of the impact of hospital service quality in the new normal era on outpatient satisfaction and loyalty, also investigated the influence between patient satisfaction and outpatient loyalty.

\section{Methods}

\section{Types of research}

This study used quantitative research to identify the independent variable (the quality of pharmaceutical services) to the dependent variable (patient loyalty and patient satisfaction). This research consisted of observation and distribution of questionnaires. Sources of data in this study were primary data sources obtained from observations and the distribution of questionnaires. Secondary data sources were obtained from literature, hospital employee performance reports, Community Satisfaction Survey Results data, Quality Improvement and Patient Safety Reports, and some data sourced from the Hospital database.

This study used an analytical survey with a cross-sectional design approach to analyze the relationship between the independent variable (risk factor) and the dependent variable (effect) by performing instantaneous measurements. It was aimed that all research subjects' variables were assessed only once simultaneously, but did not mean that all subjects of this study should be observed at one time.

\section{Research location and time}

This research was conducted at the Daya General Hospital, particularly the Pharmacy Installation, to collect primary data using a questionnaire on service quality, satisfaction, and loyalty of outpatients. Furthermore, the research was carried out in June-July 2021.

\section{Population and sample}

The population in this study was the entire number of outpatients at the Daya General Hospital in Makassar City, from January to June 2021, about 6194 people. Based on the Slovin formula, the minimum number of samples was 99 people. Based on Wijaya's theory in [3], the number of samples in the analysis rules is a basic assumption that must be fulfilled, where the Structural Equation Modeling (SEM) analysis requires a sample of at least 5 times the number of indicators of the variables used. Hair et al. are quoted in [4] that the appropriate sample size for structural analysis is 100-200 samples for the Maximum Likelihood estimation technique. In the study, there were 12 variable indicators multiplied by 10 (based on the theory of Hair et al.), so that the appropriate number of samples for the whole analysis was 120 people.

The sample that took part in this study should meet the inclusion and exclusion criteria. The inclusion criteria in this study were: outpatients at the Pharmacy Installation at the Daya General Hospital, Makassar City; aged 17-65 years old; willing to be a respondent and fill out a questionnaire; not illiterate; able to communicate well. Exclusion criteria in this study were: Patients with severe illness; employees of Daya General Hospital; The patient who visited the Daya General Hospital for the $1^{\text {st }}$ time.

\section{Research instruments}

The main instrument of this research was a questionnaire. The statements in this questionnaire were related to the quality of pharmaceutical services using five dimensions: physical evidence (tangible), reliability, responsiveness, assurance, and empathy. At the same time, satisfaction included feeling satisfied, always using pharmacy services, recommending services, and achieving the treatment expectations. As well as on the loyalty indicator, there were three dimensions, such as patient loyalty, resilience from other service providers, and referring to pharmacy services at Daya General Hospital.

\section{Data analysis}

This research used simple linear regression analysis to determine the direct effect of pharmaceutical service quality on patient loyalty and its indirect effect on outpatient satisfaction at Daya General Hospital as a mediating variable. The data were then analyzed using the SEM method using the IBM AMOS 22 program.

\section{Results}

\section{Characteristics of respondents}

The number of outpatients who became respondents in the study was 120 patients who had met the research criteria. Based on Table 1, in terms of gender characteristics, male respondents were more than female, 62 respondents and 58 respondents, respectively. Based on the age, 13 people were1724 years old, 27 people were 25-34 years old, 37 people were $35-49$ years old, and 43 people were $50-65$ years old. Based on education, 15 people graduated from primary school, 16 graduated from junior high school, 51 graduated from high school, seven held associate 
degree-diploma, and 31 had bachelor degrees. Based on the cost source, the total respondents who redeem drugs at their own expense were 17 people, private insurance users were two people, Regional health insurance was 12 people, healthcare was 20 people, and Social Health Insurance Administration was 69 people. Based on the type of disease, as many as ten respondents each suffered from diabetes mellitus and ulcers, nine people with hypertension, five people with bronchitis and eye infections, and the rest suffered from depression, anxiety disorders, migraines, allergies, asthma, Parkinson's, and others. Based on the number of visits, about 69 respondents came 1-2 times/month, 50 respondents came to visit 3-5 times a month, and one respondent visited more than 5 times a month (Table 1).

Table 1: Frequency distribution of subject characteristics

\begin{tabular}{lll}
\hline Characteristics & $\mathrm{n}$ & $\%$ \\
\hline Gender & & \\
Male & 62 & 51.7 \\
Female & 58 & 48.3 \\
Age (y.o) & & \\
17-24 & 13 & 10.9 \\
$25-34$ & 27 & 22.5 \\
35-49 & 37 & 30.8 \\
50-65 & 43 & 35.8 \\
Education & & \\
Primary school & 15 & 12.5 \\
Junior high school & 16 & 13.4 \\
Senior High School & 51 & 42.5 \\
Associate degree - Diploma & 7 & 5.8 \\
Bachelor degree & 31 & 25.8 \\
Occupation & & \\
None & 28 & 23.3 \\
Housewife & 35 & 29.2 \\
Private employees & 15 & 12.5 \\
Civil servant/Military - National Police/Pensionary & 20 & 16.7 \\
Entrepreneur & 22 & 18.3 \\
Source of costs & & \\
Own & 17 & 14.2 \\
Private health insurance & 2 & 1.6 \\
Regional health insurance & 12 & 10.0 \\
Health service & 20 & 16.7 \\
Social health insurance administration & 69 & 57.5 \\
IIIness & & \\
Diabetes mellitus & 10 & 8.3 \\
Ulcers & 10 & 8.3 \\
Hypertension & 9 & 7.6 \\
Bronchitis & 5 & 4.2 \\
Eye infection & 5 & 4.2 \\
Depression & 4 & 3.3 \\
Anxiety disorder & 4 & 3.3 \\
Migraine & 4 & 3.3 \\
Etc. & 69 & 57.5 \\
Visit (per month) & & \\
1-2 times & 69 & 57.5 \\
3-5 times & 50 & 41.7 \\
>5 times & 1 & 0.8 \\
\hline$\quad$ & & \\
$\quad$ & & \\
\hline
\end{tabular}

Based on Table 2, the total average of the research respondents' assessments of the pharmaceutical service quality, satisfaction, and loyalty was 4.18, 4.33, and 4.25, respectively. All three were included in the good category based on the mean score categorization technique with five classes.

\section{Simple regression}

Table 3 shows that service quality had a $t_{\text {count }}$ of $10.875>t_{\text {table }}$ of 1.981 with a significant level of $0.000<0.05$. This shows that the pharmaceutical service quality variable had an effect on outpatient satisfaction at Daya General Hospital. Then, patient satisfaction with patient loyalty had a $t_{\text {count }}$ of 13.049 $>t_{\text {table }}$ of 1.981 with a significant level of $0.000<0.05$. This shows that the satisfaction variable affected the loyalty of outpatients in Daya General Hospital. The summary model on the simple regression between patient satisfaction and patient loyalty with R-value was 0.769 and R-square was 0.591 . Meanwhile, the

Table 2: Average assessment of service quality, satisfaction, and loyalty

\begin{tabular}{lll}
\hline S. No. & Parameter & Average scores (1-5) \\
\hline 1. & Service quality & \\
& Tangible & 4.15 \\
& Empathy & 4.14 \\
& Reliability & 4.24 \\
& Responsiveness & 4.02 \\
& Assurance & 4.42 \\
& Average & 4.194 \\
2. & Satisfaction & 4.23 \\
& Satisfied feeling & 4.36 \\
& Always use products & 4.06 \\
& Recommending services & 4.66 \\
& Treatment expectation achieved & 4.326 \\
3. & Average & 4.33 \\
& Loyalty & 4.39 \\
& Loyalty & 4.05 \\
& Resilience from other service providers & 4.256 \\
\hline
\end{tabular}

service quality to patient loyalty had a $t_{\text {count }}$ of 7.936 $>t_{\text {table }}$ of 1.981 with a significant level of $0.000<0.05$. It means that the service quality variable affected the loyalty of outpatients at Daya General Hospital. The model summary on the simple regression between service quality and patient loyalty was with an R-value of 0.590 and an R-square of 0.348 (Table 4).

Table 3: Simple regression results of service quality on patient satisfaction, patient satisfaction on patient loyalty, and quality service on patient loyalty

\begin{tabular}{|c|c|c|c|c|c|}
\hline \multirow[t]{2}{*}{ Model } & \multicolumn{2}{|c|}{$\begin{array}{l}\text { Unstandardized } \\
\text { Coefficients }\end{array}$} & \multirow{2}{*}{$\begin{array}{l}\text { Standardized } \\
\text { Coefficients } \\
\text { Beta }\end{array}$} & \multirow[t]{2}{*}{$\mathrm{t}$} & \multirow[t]{2}{*}{ Sig. } \\
\hline & $\mathrm{B}$ & Std. Error & & & \\
\hline \multicolumn{6}{|c|}{ Service quality on patient satisfaction* } \\
\hline (Constant) & 4.454 & 1.993 & & 2.235 & 0.027 \\
\hline Service quality & 0.224 & 0.021 & 0.708 & 10.875 & 0.000 \\
\hline \multicolumn{6}{|c|}{ Patient satisfaction on patient loyalty** } \\
\hline (Constant) & 1.322 & 0.883 & & 1.497 & 0.137 \\
\hline Patient satisfaction & 0.44 & 0.034 & 0.769 & 13.049 & 0.000 \\
\hline \multicolumn{6}{|c|}{ Service quality on patient loyalty ${ }^{\star \star *}$} \\
\hline (Constant) & 2.476 & 1.303 & & 1.900 & 0.060 \\
\hline Service quality & 0.107 & 0.013 & 0.59 & 7.936 & 0.000 \\
\hline
\end{tabular}

\section{SEM}

Figure 1 shows the structural model of the research data and the standardized estimates of intervariable and inter-indicator values.

Table 4: Summary model of service quality on patient satisfaction, service quality on patient loyalty, and service quality on patient loyalty satisfaction

\begin{tabular}{|c|c|c|c|c|}
\hline Model & $R$ & R Square & Adjusted R Square & $\begin{array}{l}\text { Std. Error of } \\
\text { the Estimate }\end{array}$ \\
\hline $\begin{array}{l}\text { Service quality on patient } \\
\text { satisfaction* }\end{array}$ & $0.708^{a}$ & 0.501 & 0.496 & 2.197 \\
\hline $\begin{array}{l}\text { Patient satisfaction on patient } \\
\text { loyalty**}\end{array}$ & $0.769^{\mathrm{a}}$ & 0.591 & 0.587 & 1.138 \\
\hline $\begin{array}{l}\text { Service quality on patient } \\
\text { loyalty***}\end{array}$ & $0.590^{\mathrm{a}}$ & 0.348 & 0.342 & 1.437 \\
\hline
\end{tabular}




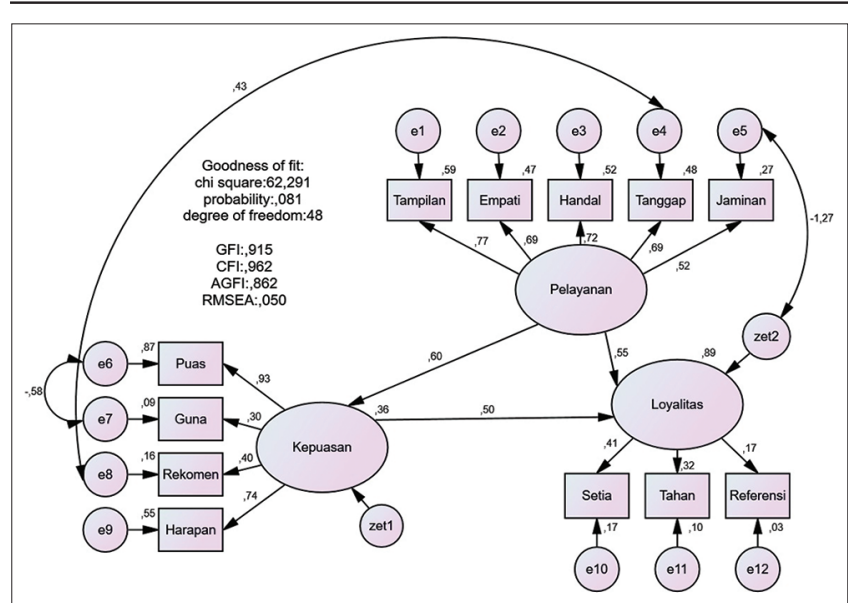

Figure 1: Structural Equation Model. E1: tangible; E2: empthy; E3: reliability; E4: responsiveness; E5: Assurance $\rightarrow$ Service, E6: satisfied; E7: Usage; E8: Recommending; E9: expectation $\rightarrow$ Satisfaction, E10: Loyalty; E11: Resilience; E12: Reference

\section{Test of fit (goodness of fit)}

Table 5 shows the Model Fit value in the AMOS 22 program where the probability of the model made was 0.081; Chi-Square value was 62.291; CMIN/DF value was 6.720; Goodness of Fit Index (GFI) value was 0.915; Adjust Goodness of Fit Index (AGFI) value was 0.862; Tucker-Lewis Index (TLI) value was 0.948; Comparative Fit Index (CFI) was 0.962; and Root Mean Square Error of Approximation (RMSEA) value was 0.5.

Table 5: Results of model fit summary

\begin{tabular}{ll}
\hline Model & Default Model \\
\hline Probability & 0.081 \\
Chi-Square & 62.291 \\
CMIN/DF & 1.298 \\
GFI & 0.915 \\
AGFI & 0.862 \\
TLI & 0.948 \\
CFI & 0.962 \\
RMSEA & 0.050 \\
\hline GFI: Goodness of fit index, AGFI: Adjust goodness of fit index, TLI: Tucker-Lewis index, CFI: Comparative
\end{tabular}

fit index, RMSEA: Root mean square error of approximation

\section{Direct and indirect effects}

Table 6 shows that the direct effect of service quality on satisfaction was 0.601 while service quality on patient loyalty was 0.550 . The direct effect of satisfaction on patient loyalty was 0.505 . Furthermore, the indirect effect of service quality on patient loyalty was 0.303 .

Table 6: Direct and indirect effects

\begin{tabular}{llll}
\hline Variables & Service quality & Patient satisfaction & Patient loyalty \\
\hline Direct effects & & & - \\
$\quad$ Patient satisfaction & 0.601 & - & - \\
Patient loyalty & 0.550 & 0.505 & - \\
Indirect effects & & - & - \\
$\quad$ Patient satisfaction & - & - & - \\
Patient loyalty & 0.303 & - & \\
\hline
\end{tabular}

\section{Discussion}

Overall, the average score of respondents' assessment of the quality of pharmaceutical services at the Daya General Hospital during the new normal period was 4.18 , included in the good category. Then, in general, the average score of respondents' assessment of the Satisfaction variable was 4.33 , meaning that patient satisfaction with pharmaceutical services obtained was very satisfied. Meanwhile, the average score of respondents' assessment of the loyalty variable was 4.25 , which means that the loyalty of outpatients at the pharmacy installation shows the very loyal category. It means that the quality of pharmaceutical services at the Daya General Hospital in the new normal era was generally considered good, provided an adequate level of satisfaction, and increased patient loyalty.

\section{satisfaction}

\section{The effect of service quality on patient}

According to Zeithaml et al., quoted in Handayany (2020) [5], the quality of pharmaceutical services includes five dimensions, such as physical evidence, reliability, responsiveness, assurance, and empathy that have an impact on the comfort and satisfaction felt by patients [5].

This study shows the results of a simple regression to determine the effect of pharmaceutical service quality on patient satisfaction using the Enter method. According to the Statistical Package for the Social Sciences output table, it can be seen that service quality had a significance value of 0.000 and $t_{\text {count }}$ of $10.875>t_{\text {table }}(1.981)$. This shows that the pharmaceutical service quality variable had an effect on outpatient satisfaction at Daya General Hospital. Then, based on the summary model, it was concluded that the correlation between pharmaceutical service quality and patient satisfaction was 0.708 , a close relationship between the two variables since the R-value was close to 1 . While the R-Square value of the study was 0.501 , it means that the percentage of the service quality variable that affects satisfaction was $50.1 \%$, and the rest was affected by other variables not included in the study.

The results of this study were in line with the research of Addo et al. (2020) [6] that the quality of pharmaceutical services had a positive impact on patient satisfaction where the higher the quality of pharmaceutical services provided, the greater the level of satisfaction felt by patients. Likewise, Mardiana et al. (2019) [7] concluded a significant influence between service quality and outpatient satisfaction at Bayu Asih Hospital.

\section{Effect of satisfaction on patient loyalty}

According to Zeithaml et al., quoted in Handayany (2020) [5], the quality of pharmaceutical services includes five dimensions, including physical evidence, reliability, responsiveness, assurance, and empathy, that affect the comfort and satisfaction felt 
by patients [5]. The results of the linear regression test between satisfaction and loyalty showed a significance value of 0.000 and $a t_{\text {count }}$ value of $3.049>t_{\text {table }}$ (1.981). Hence, it can be concluded that the satisfaction variable affected patient loyalty in the Pharmacy Installation of Daya General Hospital. The summary model shows the $\mathrm{R}$-value of the output was 0.769 , and the R-Square was 0.591 . Thus, it can be concluded that the correlation between satisfaction and loyalty of outpatients at Daya General Hospital was very close by showing an R-value of 0.769 , which was close to 1 . While the resulting $\mathrm{R}$-Square value was 0.591 , it can be concluded that the percentage of satisfaction variable affecting loyalty was $59.1 \%$, and the rest was influenced by other variables not included in the study.

The results obtained were in line with the research of Kulsum and Syah (2017) [8], which concluded that there is an effect of patient satisfaction on patient loyalty where the higher the patient satisfaction, the more loyal the patient is. Research by Addo et al. (2020) [6] also shows the same result that there is a positive influence of the patient satisfaction variable on loyalty which proves the effect is significant.

\section{loyalty \\ The effect of service quality on patient}

The results of the linear regression test between service quality and loyalty showed a significance value of 0.000 and $a t_{\text {count }}$ of $7.936>t_{\text {table }}$ (1.981). Hence, it can be concluded that the satisfaction variable affects patient loyalty in the Pharmacy Installation of Daya General Hospital. Model summary of simple linear regression tests between the variables of service quality and patient loyalty. It can be seen that the R-value of the output was 0.590 and the R-Square value was 0.348 . Thus, it can be concluded that the correlation between service quality and outpatient loyalty at Daya General Hospital was quite close by showing an R-value of 0.590 , which was close to 1 . While the resulting $R$ Square value was 0.348 , it can be concluded that the percentage of service quality variable affecting loyalty was $34.8 \%$, and the rest was influenced by other variables not included in the study.

Based on the description above, the results of this study follow the research by Kulsum and Syah (2017) [8], concludes that a significant positive influence is formed between service quality and patient loyalty. The quality of pharmaceutical services significantly influences patient loyalty in hospitals and the community [9], [10], [11].

\section{SEM}

A structural equation model or SEM is a model that explains the relationship between latent variables; it is commonly called latent variable analysis or linear structural relationship. The relationship between variables in SEM forms a structural model, which can be explained by structural equations [3]. From the SEM model generated in Figure 1, it can be seen that the most dominant indicator in the service quality variable was a physical appearance with a loading factor of 0.77 . This proved that the aspect of physical appearance was the most important aspect for research respondents. In the physical appearance indicator, four items lead to health protocols in the new normal era. Meanwhile, the lowest aspect was the assurance, with a loading factor value of 0.52 . Based on research Arnaya and Niryana (2020) [12], the tangibles indicator is the dominant aspect of service quality where service providers are required to provide maximum resources in their services, both in terms of equipment and service providers.

While in the satisfaction variable, the most dominant indicator was patient satisfaction, with a loading factor of 0.93 . This proved that the aspect of feeling satisfied was the most important aspect for research respondents. The satisfaction felt by patients is the most important indicator to examine the level of patient satisfaction [6], [13], [14].

As for the loyalty variable, the most dominant indicator was loyalty, with a loading factor of 0.41 . This proved that the loyalty aspect was the most important aspect for research respondents. Patient loyalty is the most appropriate indicator to measure service user loyalty [15], [16].

\section{Fit test (goodness of fit)}

According to Hair et al. quoted in Haryono (2016) [3], from the results of several feasibility tests, if at least one of the model's feasibility test methods is met, the model is considered feasible. The goodness of fit is divided into three types, namely, absolute fit measure, incremental fit measure, and parsimony fit measure. Absolute match sizes include Chi-squared, CMIN, CMIN/DF, NCP, SNCP, GFI, RMSR, RMSEA, and ECVI. In this test, the RMSEA results can show the feasibility of the model, so the RMSEA value must be met to continue the structural model [3]. In this study, it was known that the probability value of the model was $0.081 \geq 0.05$ so that the structural model could be accepted. The Chi-Square value obtained was 62.291, with the degree of freedom value was $48,<65.170$, so it was accepted in the modeling. Based on [3] that the CMIN/DF value was to measure fit, the study obtained CMIN/DF $1.298<2.00$, so it can be said that the model was fit. The GFI value obtained in the study was 0.915 . According to Haryono (2016) [3], the GFI value can be classified as an absolute fit measure with the provisions that 0.90 is a good fit and $0.80-0.90$ is marginal fit. Hence, it can be said that the value of GFI in the study included a good fit.

The AGFI value in this study was 0.862 . Based on Haryono (2016) [3], the AGFI value 0.90 is the cutoff value; the closer it is, the more feasible the model will be, and the closer to 0 the model is considered 
unfeasible. The study results found that the AGFI value was close to 0.90 , so the modeling was feasible. Based on Table 5., the TLI value from the analysis was 0.948 . According to Haryono S (2016) [3], the TLI value was a means to evaluate extended factor analysis for SEM. The TLI value ranges from 0 to 1 , with 0.9 indicating good fit and 0.8-0.9 indicating marginal fit. Hence, it can be said that the TLI value in the study shows that the model made included a good fit. The CFI value of the study was 0.962. Based on Haryono (2016) the CFI value was used to see the suitability of the incremental model [3]. CFI values ranged from 0 to 1 , with 0.9 indicating a good fit and $0.8-0.9$ indicating a marginal fit. Hence, it can be said that the CFI value in the study shows that the model made included a good fit. The RMSEA value was 0.962. Based on Haryono (2016) [3], the RMSEA value is an informative index in SEM used to test confirmatory models in many samples. RMSEA value 0.05 indicates a close fit, while the value 0.05 0.08 is a good fit. Hence, it can be said that the model made included a close fit based on the RMSEA index.

\section{Direct and indirect influence}

Impact analysis aims to determine the significance of a variable affects other variables. This influence can be seen in terms of direct or indirect influence mediated by the mediator variable in the study. Interpretation of these results is important to determine a clear strategy to improve performance in an organization [3].

Researchers can also analyze the strength of the relationship/influence between variables in the structure, including direct, indirect, and overall effects. The direct effect is the line coefficient with a singlepointed arrow, appearing in the two constructs indicated by the one-way arrow. Indirect effects appear through an intermediate variable and appear in two constructs that are not indicated by a one-way arrow. The total effect is the combination of various relationships; the total effect is a combination of direct and indirect effects [4].

The direct effect analysis with AMOS showed that the direct influence of service quality on satisfaction was 0.601 . The effect of satisfaction on loyalty was 0.505 , while the direct effect of service quality on patient loyalty was 0.550 . These calculations indicated that the service quality variable had a greater direct influence on patient loyalty (by 0.550 ) than the direct effect of satisfaction on patient loyalty (by 0.505 ). The results obtained align with Panvelkar et al. [17], Swain [18], Agu KA et al. [19], there is a direct relationship between pharmaceutical services and patient satisfaction. Vigaretha and Handayani (2018) also show that service quality directly affects the loyalty of outpatients at General Hospital of Dr. Sudirman Mangun Sumarso. Thus, improving the quality of service will increase patient loyalty [20]. The results of this study are also in line research of Adil et al. (2016) [21] which concluded that the direct effect of service quality on loyalty is greater than the direct effect of satisfaction on patient loyalty. Based on Table 6 shows the results of the indirect effect analysis between service quality and loyalty mediated by patient satisfaction were 0.303 .

The results of this study indicated that the direct effect of service quality on loyalty (by 0.550 ) was greater than the indirect effect (by 0.303). The direct effect can be seen at $55 \%$, while the indirect effect was $30.3 \%$. Based on the above description, this research aligns with [15], [22], [23], that patient satisfaction acts as a mediating variable in service quality on patient loyalty [9] also proves that the general patient satisfaction variable mediates the indirect effect between service quality and patient loyalty [6] also concludes that pharmaceutical services indirectly have a significant effect of 0.36 on patient loyalty, mediated by patient satisfaction.

\section{Conclusion}

Satisfaction affected the loyalty of outpatients at the Pharmacy Installation of the Daya General Hospital, Makassar City, with a value of $t_{\text {count }}$ (13.049) $>t_{\text {table }}(1.981)$, with a significant level of $0.000<0.05$. The most dominant indicator was feeling satisfied in the satisfaction variable, with a loading factor of 0.93 . In the loyalty variable, the most dominant indicator was the loyalty aspect, with a loading factor of 0.41 . The direct effect of pharmaceutical service quality on loyalty was 0.550 , while the indirect effect mediated by patient satisfaction was 0.303 . Thus, it was known that the direct effect was greater than the indirect effect of service quality on the loyalty of outpatients at Daya General Hospital.

\section{References}

1. Rusly. Farmasi Rumah Sakit dan Klinik. Jakarta: Kementerian Kesehartan RI; 2016.

2. Noviyanti N. Faktor Pelayanan Yang Profesional Terhadap Kepuasan Pasien. Surabaya: Penerbit Qiara Media; 2020. p. 66.

3. Haryono S. Metode SEM Untuk Penelitian Manajemen dengan MOS LISREL PLS. Bekasi: Intermedia Personalia Utama; 2016.

4. Waluyo M. Mudah Cepat Tepat Penggunaan Tools AMOS Dalam Aplikasi (SEM). Surabaya, Jawa Timur: UPN Veteran; 2016.

5. Handayany GN. Kualitas Pelayanan Kefarmasian dan Kepuasan Pasien. Makassar: Universitas Islam Negeri Alauddin; 2020. Available from: http://www.repositori.uin-alauddin.ac.id/17873 [Last accessed on 2021 Oct 15]. https://doi.org/10.24252/ Ip.2012v15n1a5 
6. Addo AA, Wang W, Dankyi AB, Abban OJ, Bentum-Micah G. Sustainability of health institutions: The impact of service quality and patient satisfaction on loyalty. Eur $\mathrm{J}$ Bus Manag Res. 2020;5(4):1-7. Available from: https://www.ejbmr.org/index.php/ ejbmr/article/view/345 [Last accessed on 2021 Oct 15]. https:// doi.org/10.24018/ejbmr.2020.5.4.345

7. Mardiana LA, Aritonang A, Derriawan D. The Effect of Service Quality and Perceived Quality on Patient Satisfaction BPJSOutpatient Health RSUD Bayu ASIH Purwakarta. Med Tadulako J IIm Kedokt Fak Kedokt Dan IImu Kesehat. 2019 Aug 23;6(2):132-9. https://doi.org/10.23917/dayasaing. v18i2.4508

8. Kulsum U, Syah TY. The effect of service quality on loyalty with mediation of patient satisfaction. Int J Bus Manag Invent. 2017;6(3):41-50.

9. Kristina $\mathrm{S}$, Lienaningrum AS, Aditama $\mathrm{H}$. Assessing patient satisfaction with community pharmacy services in Yogyakarta, Indonesia. Int J Pharm Res. 2021;13(1):1-5.

10. Barghouth D, Al-Abdallah GM, Abdallah AB. Pharmacy service factors and pharmacy performance: The role of patient satisfaction in community pharmacies. Int J Pharm Healthc Mark. 2021;15(3):410-28. https://doi.org/10.1108/ijphm-03-2020-0017

11. Bratkowska K, Religioni U, Krysiński J, Merks P. Quality of pharmaceutical services in independent pharmacies and pharmacy chains in poland from the patient perspective. Patient Prefer Adherence. 2020;14:2459-67. https://doi.org/10.2147/ PPA.S284014

PMid:33363362

12. Arnaya AA, Niryana IW. Level of Satisfaction and Expectations of Outpatients on the Quality of Health Services at the Mengwi I Community Health Center. E-J Med Udayana. 2020 Sep 22;9(9):105-13. https://doi.org/10.33857/jns.v2i2.185

13. Batbaatar E, Dorjdagva J, Luvsannyam A, Savino MM, Amenta P. Determinants of patient satisfaction: A systematic review. Perspect Public Health. 2017;137(2):89-101. https://doi. org/10.1177/1757913916634136 PMid:27004489

14. Pakdil F, Harwood TN. Patient satisfaction in a preoperative assessment clinic: An analysis using SERVQUAL dimensions. Total Qual Manag Bus Excell. 2005;16(1):15-30. https://doi. org/10.1080/1478336042000255622

15. Nurmiwiyati N, Ds AO, Aritonang MGS, Kosasih K. Effect of Drug
Availability and Quality of Pharmacy Services on Outpatient Satisfaction and Loyalty (Study at PKU Muhammadiyah Cipondoh Maternal and Child Hospital, Tangerang). J Surya Med JSM. 2020 Aug 29;6(1):32-8. https://doi.org/10.33084/jsm. v6i1.1474

16. de Oliveira LA, de Albuquerque AP, de Carvalho RC, de Medeiros DD. What determines patient loyalty in health services? An analysis to assist service quality management. Total Qual Manag Bus Excell. 2021;1(1):1-19. https://doi.org/1 0.1080/14783363.2021.1960500

17. Panvelkar PN, Saini B, Armour C. Measurement of patient satisfaction with community pharmacy services: A review. Pharm World Sci. 2009;31(5):525-37. https://doi.org/10.1007/ s11096-009-9311-2 PMid: 19588267

18. Swain S, Kar NC. Hospital service quality as antecedent of patient satisfaction-a conceptual framework. Int J Pharm Healthc Mark. 2018;12(3):251-69. https://doi.org/10.1108/ ijphm-06-2016-0028

19. Agu KA, Oqua D, Agada P, Ohiaeri SI, Adesina A, Abdulkareem $\mathrm{MH}$, et al. Assessment of satisfaction with pharmaceutical services in patients receiving antiretroviral therapy in outpatient HIV treatment setting. Int J Clin Pharm. 2014;36(3):636-47. https://doi.org/10.1007/s11096-014-9948-3 PMid:24736896

20. Vigaretha G, Handayani OWK. The Role of Patient Satisfaction as a Mediation Variable Influence of Service Quality on Patient Loyalty. HIGEIA J Public Health Res Dev. 2018 Oct 31;2(4):543_ 52. https://doi.org/10.15294/higeia.v2i4.23893

21. Adil A, Syamsun M, Najib M. The Influence of Service Quality and Cost on Patient Satisfaction and Loyalty in Bogor City Hospital. J Apl Manaj. 2016 Sep 1;14(3):432-41. https://doi. org/10.18202/jam23026332.14.3.04

22. Fatima T, Malik SA, Shabbir A. Hospital healthcare service quality, patient satisfaction and loyalty: An investigation in context of private healthcare systems. Int $\mathrm{J}$ Qual Reliab Manag. 2018;35(6):1195-214. https://doi.org/10.1108/ ijqrm-02-2017-0031

23. Wu CC. The impact of hospital brand image on service quality, patient satisfaction and loyalty. Afr J Bus Manag. 2011;5(12):4873-82. 